УДК 93/94:336.114/338.001.36/311.218

DOI: 10.24919/2519-058x.6.123761

Наталя ПАСІЧНИК,

orcid.org/0000-0002-0923-9486

кандидат педагогічних наук, дочент кафедри прикладної математики,

статистики та економіки

Центральноукраӥнського державного педагогічного університету імені Володимира

Винниченка (Украӥна, Кропивницький)

pasichnyk1809@gmail.com

\title{
ТЕОРЕТИЧНІ ІДЕЇ ТА ПРАКТИЧНА ДІЯЛЬНІСТЬ ДЕРЖАВНИХ ДІЯЧІВ РОСІЙСЬКОЇ ІМПЕРІЇ ПОЧАТКУ ХІХ СТОЛІТТЯ У СФЕРІ ФІНАНСОВОГО УПРАВЛІННЯ
}

\begin{abstract}
Стаття присвячена аналізу діяльності знакових реформаторів російських фінансів початку XIX століття - М. М. Сперанського та М. А. Балудянського, а саме визначенню основних ідей иих державних діячів щодо поліпшення фінансового управління в Російській імперії та аналізу результатів реалізації ијих ідей у бюджетному прочесі протягом 1810 - 1814 рр.

Задекларовані реформи не були реалізовані в повному обсязі через постійну участь Російської імперії у воєнних компаніях, але заклали ідеї щодо підведення правового фундаменту під процес щорічного затвердження бюджету, ичивілізованих норм управління держсавними фінансами, єдиної бюджетної класифікацію доходів і витрат.
\end{abstract}

Ключові слова: фінансове господарство, бюджет, доходи, витрати, податки, асигнації, реформа.

Natalia PASICHNYK, PhD (Education), Associate Professor of Applied Mathematics, Statistics and Economics Department, Volodymyr Vynnychenko Central Ukraine State Pedagogical University (Ukraine, Kropyvnytskyi) pasichnyk1809@gmail.com

\section{THE THEORETICAL IDEAS AND PRACTICAL ACTIVITIES OF THE STATESMEN OF THE RUSSIAN EMPIRE AT THE BEGINNING OF THE XIX CENTURY IN THE FIELD OF FINANCIAL MANAGEMENT}

The article analyzes the activity of the renowned figures of Russian finance at the beginning of the nineteenth century - Mikhail Mikhailovich Speranskiy and Mikhail Andriyovych Baludianskiy, who significantly influenced the organization of activities of the national government bodies and, specifically, the ministers of finance, and also influenced the definition of the tax policy of the state, the main financial document of the state - the description of revenues and expenditures (budget) of the Russian Empire in general and the formation of the structure of the revenue and expenditure parts of the budget in particular, as well as measures to overcome the budget deficit and the actual implementation of the planned budget indicators.

In preparing of the study, the author aimed to determine the main ideas of state figures M. M. Speranskiy and M.A. Baludianskiy to improve the financial management in the Russian Empire and to analyze how these ideas were implemented in the budget process during $1810-1814$.

The main program of M. M. Speranskiy and M. A. Baludianskiy was known as the "Finance Plan» that consisted of two parts: the budget planning of 1810 and the planning of the state budget for subsequent years. At the same time, the innovation of the strategy and its main content consisted in refusing of assignation ruble, expenditure reduction, establishment of control over the state expenditures and introducing new taxes. The reform of financial management took place in the process of general changes in the system of central and executive power, which were as follows: the establishment of a state council, creation of state control, optimization of the structure of distribution of ministries and their internal structure, change in distribution of the official duties of ministers and their subordinates.

The theoretical ideas and practical activity of such state figures, as M. M. Speranskiy and M. A. Baludianskiy, occupy an important place in the history of financial management of the Russian Empire. The reforms conducted by 
M. M. Speranskiy and M. A. Baludianskiy gave the idea of putting the legal foundation under the process of annual approval of the budget and granting the status of state law. Besides, these ideas declared the public and civilized norms of public finance management of that time, strict control over the planned expenditures and revenues of agencies, a single budget classification of revenues and expenditures for budgets of all levels. During the first two years of the reforms at the expense of higher taxes, the authors of the reform managed to increase the revenue part of the budget and substantially reduce its deficit. However, these theoretical and practical achievements of the reformers were not fully implemented in the early nineteenth century because of the constant participation of the Russian Empire in military campaigns, which led to an uncontrolled growth of military budgets, as well as through bureaucratic corruption and due to the elemental non-enforcement orders of the central government.

Key words: financial economy, budget, income, expenses, taxes, assignments, reform.

Наталья ПАСЕЧНИК, кандидат педагогических наук, доцент кафедры прикладной математики, статистики и экономики Центральноукраинского государственного педагогического университета имени Владимира Винниченко (Украина, Кропивницкий) pasichnyk1809@gmail.com

\section{ТЕОРЕТИЧЕСКИЕ ИДЕИ И ПРАКТИЧЕСКАЯ ДЕЯТЕЛЬНОСТЬ ГОСУДАРСТВЕННЫХ ДЕЯТЕЛЕЙ РОССИЙСКОЙ ИМПЕРИИ В НАЧАЛЕ ХІХ ВЕКА В СФЕРЕ ФИНАНСОВОГО УПРАВЛЕНИЯ}

Статья посвящена анализу деятельности знаковых реформаторов российских финансов начала ХІХ века - М. М. Сперанского и М. А. Балудянскому, а именно определению основных идей этих государственных деятелей по улучшению финансового управления в Российской империи и анализу результатов реализации этих идей в бюджетном прочессе в течение 1810 - 1814 г2.

Задекларированные реформы не были реализованы в полном объеме из-за постоянного участия Российской империи в военных компаниях, но заложили идеи по подведению правового фундамента под процесс ежегодного утверждения бюджета, иивилизованных норм управления государственными финансами, единой бюджетной классификации доходов и расходов.

Ключевые слова: финансовое хозяйство, бюджет, доходы, расходы, налоги, ассигнации, реформа.

Постановка проблеми. Значний вплив на розвиток фінансово-правової думки в першій чверті XIX ст. мали державні діячі, які в силу своїх службових обов'язків стали практиками фінансового права й заклали основи наукових підходів до фінансово-правової проблематики. Чиновники, які стали науковцями, й науковці, що стали чиновниками (Лушникова, Лушников, 2013а: 62), були представниками різних наукових шкіл і течій, проте вони оперували актуальною й об'єктивною інформацією про стан державних фінансів і мали можливості впливати на практичну реалізацію власних ідей у сфері фінансового управління й фінансового законодавства.

Початок XIX ст. Російська імперія зустріла у постійних війнах та конфліктах, з небувалим розвитком чиновництва та казнокрадства, з колосальними державними фінансовими проблемами. Певні надії пов'язувалися зі вступом на престол молодого царя Олександра I, який від самого початку каденції мав рішучі наміри щодо реформування суспільного, політичного та фінансового устрою в державі. Як наслідок, запровадження у 1802 р. міністерств замість колегій, поява серед політичної еліти прогресивних фінансистів, якими були Михайло Михайлович Сперанський та Михайло Андрійович Балудянський (Балуг'янський). Саме під ідейним та практичним керівництвом цих знакових фігур на початку XIX ст. в Російській імперії розпочалися реформи фінансового господарства, що суттєво вплинули на організацію діяльності загальнодержавних органів управління та конкретно міністерства фінансів, на визначення податкової політики держави, на основний фінансовий документ держави - розпис доходів і витрат (бюджет) Російської імперії загалом, а також на визначення структури дохідної та витратної частин бюджету зокрема, а також на заходи з подолання бюджетного дефіциту і на фактичне виконання запланованих бюджетних показників. 
Аналіз досліджень. Фінансовим реформам в Російській імперії початку ХІХ ст. приділили значну увагу спеціалісти з економічної історії та фінансів, фахівці з історії права та дослідники діяльності державних інститутів влади. Класичним дослідженням вважається 4-томна праця І. Бліоха $з$ історії реформування, впорядкування й аналізу основних статистичних показників розвитку фінансів Російської імперії ХІХ ст. (Блиох, 1882). Професор фінансового права Харківського університету П. Мігулін у своєму історико-критичному огляді (1899) проаналізував закономірності розвитку російського державного кредиту протягом значного періоду - 3 другої половини XVII до кінця XIX ст. (Мигулин, 1899). Я. Печеріним був представлений історичний огляд розписів державного бюджету Російської імперії протягом дореформеного періоду (Печерин, 1896). Історичний огляд найголовніших заходів міністерства фінансів Російської імперії XIX ст. міститься у працях (Министерство финансов, 1902a), (Министерство финансов, 1902b). Досить важливий фактичний матеріал, що підтверджував вплив фінансових реформ початку XIX ст. на реформування фінансів у післяреформений період, міститься у матеріалах, де представлені загальні державні розписи доходів та витрат Російської імперії протягом 1867 - 1917 рр. (Исторический бюджет России). Досить широкий фактаж подій з історії фінансів початку XIX ст. поданий у курсі історії Росії XIX ст. О. Корнілова (Корнилов, 1993). У різноманітних джерелах також детально описані біографічні деталі, академічна та державна діяльність М. Сперанського та М. Балудянського (див. (Лушникова, Лушников, 2013b), (Корф, 1861), (Голубка, 2012), (Фатеев, 1931)).

У сучасній науковій літературі еволюція системи державних фінансів та фінансового управління імперського періоду також досліджують представники різноманітних галузей знань - історії, економіки, юриспруденції: О. Бец (Бец, 2013), Д. Ігнатенко (Игнатенко, 2012), В. Лісовенко (Лісовенко та ін., 2014), О. Морозов (Морозов, 2011), В. Орлик (Орлик, 2007)], В. Небрат (Небрат, 2013), В. Хохуляк (Хохуляк, 2012), І. Чуркіна (Чуркіна, 2014) та ін. Майже у всіх вищезазначених дослідженнях реформування російської державності і фінансів пов'язується з ім'ям М. Сперанського і недостатньо враховується вклад вченого-практика М. Балудянського у становлення і розвиток фінансово-правої науки й практики фінансового управління. За запискою, складеною М. Балудянським (1816), окрім теоретичних праць (8-томна праця з політичної економії і фінансів, записки про фінансову адміністрацію з Петра I до 1812 р., опубліковані праці з фінансової проблематики (Балудянский, 1806a), (Балудянский, 1806b), (Балудянский, 1808), можна відзначати його вклад у різноманітні проекти: реорганізації міністерств, селянських законів, різноманітних фінансових заходів, у тому числі «Плану фінансів» (1810), фінансового плану 1814 р., утворення кредитних установ і банків та ін. (Алмазов, 1889: 80-83).

Мета дослідження - визначити основні ідеї державних діячів М. Сперанського та М. Балудянського щодо поліпшення фінансового управління в Російській імперії та проаналізувати, наскільки ці ідеї було реалізовано в бюджетному процесі протягом перших чотирнадцяти років XIX ст.

Виклад основного матеріалу. Саме М. Сперанському та М. Балудянському належать ідеї та супроводження практичного впровадження процесу реформування системи державного управління, практичні рекомендації щодо організації й реалізація управління розробкою програми поліпшення управління фінансами (носила назву «План фінансів»), що було зумовлювалося насамперед гострою необхідністю застосування термінових заходів щодо нормалізації фінансової системи держави. Головними практичними задачами «Плану фінансів» були пошук можливостей переходу від неефективного емісійного способу фінансування державного бюджету та повернення до традиційних, більш надійних і перевірених джерел фінансування. Однак самі перетворення виявилися набагато ширшими - вони торкалися не лише бюджетної та сфери грошового обігу, а й організаційної структури державних установ.

Найголовнішою ідеєю М. Сперанського у реформуванні системи державного управління стало створення державної ради, що мало привести до розподілу влади на законодавчу, виконавчу та судову. Це номінально було реалізовано 1 січня 1810 р. під час засідання державної ради у Зимовому палаці під головуванням безпосередньо царя Олександра І. Цього ж дня був виданий відповідний маніфест (Блиох, 1882: 89-90). Найголовнішим досягненням створення державної ради як законодавчого органу Російської імперії мала стати ії̈ публічність, оскільки метою нової урядової системи було отримання довіри суспільства не до окремої особи, а до міцності державних установ. 3 метою 
раціональної організації обговорення законодавчих актів державна рада була розділена на чотири департаменти: департамент законів, департамент військових справ, департамент громадянських та духовних справ та департамент державної економії (Блиох, 1882: 91). Секретарем державної ради був призначений М. Сперанський, а керівником департаменту державної економії - адмірал Н. Мордвинов.

М. Сперанський і М. Балудянський розуміли всю складність тогочасного фінансового становища держави: згідно з плануванням бюджету 1810 р. держава мала 125 млн. руб. доходів, 230 млн. руб. витрат і 577 млн руб. боргів (Блиох, 1882: 93) (за версією Я. Печеріна - дохід 105 млн. рублів, витрати - 225 (Печерин, 1896: 19)). При цьому зазначимо, що першою важливою подією в області фінансів Російської імперії XIX ст. став виданий царем Олександром I указ (1802) про створення міністерств (ї було 8 - військово-сухопутне, морських сил, іноземних справ, юстиції, внутрішніх справ, фінансів, комерції та народної освіти). Права та обов'язки міністра фінансів (першим був граф О. Васильєв, 1806 р. його змінив Ф. Голубцов, 1810 - Д. Гур'єв) полягали, з одного боку, в управлінні казенними та державними частинами, які забезпечували фінансову діяльність уряду, 3 іншого боку, складання державних загальних розписів доходів та витрат (Блиох, 1882: 71). Кожне міністерство зобов'язане було до початку жовтня надавати міністерству фінансів детальний план необхідних на наступний фінансовий рік витрат. У випадку перевищення витрат над доходами завданням саме міністра фінансів було знаходження способів покриття бюджетного дефіциту. Тобто, особливість бюджетів того періоду полягала у первинності витрат відносно доходів, а також у тому, що кожне відомство саме визначало для себе необхідний обсяг витрат і тільки потім вишукувалися джерела їх покриття. Таким чином, за 8 років існування міністерства фінансів державні фінансові справи лише погіршувалися (Блиох, 1882: 93), (Печерин, 1896: 1-2). 1810 року саме М. Сперанському було доручено складання плану фінансових перетворень, який він разом з М. Балудянським у вигляді доповіді на 238 статей успішно представив на розгляд імператора (Печерин, 1896: 12).

«План фінансів» складався з двох частин: планування бюджету 1810 р. та планування державного бюджету на наступні роки (Печерин, 1896: 13). Основний зміст «Плану фінансів» полягав у запровадженні «сильних заходів та важливих пожертвувань» - відмова від випуску асигнацій, скорочення витрат, встановлення контролю за державними витратами, запровадження нових податків. У результаті розгляду фінансового плану державною радою був виданий маніфест (від 2 лютого 1810 р.) про стратегію уряду щодо оздоровлення фінансів (Блиох, 1882: 94), (Мигулин, 1899: 46). Документом передбачалося проведення таких заходів: визнання усіх державних банківських асигнацій державним боргом; припинення нових випусків асигнацій; створення розмінних контор для оптимізації обігу асигнацій, скорочення державних витрат (загальна сума на 1810 р. планувалася на рівні 20 млн. рублів); затвердження всіх надзвичайних витрат винятково державною радою; здійснення всіх державних видатків та обрахунок всіх державних доходів казначейством; збільшення подушної податі («со всех казенных, удельных и помещичьих крестьян, по ревизии в окладе состоящих, равным числом по два рубля с души» (Блиох, 1882: 95)), оброчної податі (з казенних селян у розмірі від двох до трьох рублів залежно від класу губернії), торгової податі (із селян-торгівців від 25 до 100 рублів з кожної лавки; з іноземних ремісників - від 20 рублів для учнів до $100-$ для майстрів), збору з домів (в обох столицях у розмірі 0,5 \%), гільдійського мита (25 рублів понад актуальною податтю та по 1,25 \% 3 капіталів, заявлених по гільдії; понад оплати гільдійського мита 0,5 \% з рубля заявлених купецьких капіталів), державної ціни на сіль ( 40 копійок до 1 рубля за пуд) та гербовий папір (подвоїти та потроїти в ціні), митних зборів (з 2,1 рубля асигнаціями за талер до 4 рублів асигнаціями); запровадження податків від дворянських станів (по 50 копійок 3 кожної ревізької душі) та податі на виплавлену мідь (по 3 рублі за пуд понад десятинною податтю); запровадження складання і затвердження розписів державних доходів та видатків (Блиох, 1882: 95-96), (Мигулин, 1899: 46).

На виконання цих намірів у новому проекті бюджету на 1810 р. доходи зросли на 104 млн руб. порівняно з початковим розписом (з 105 до 209 млн. руб.), а витрати були зменшені з 230 до 184 млн. руб. (Мигулин, 1899: 47), (Печерин, 1896: 19). Бюджетний розпис було затверджено 3 профіцитом в 25 млн. руб. Однак на практиці виконати затверджений бюджет не вдалося - витрати 
1810 р. склали 241,5 млн. руб., а замість запланованого профіциту утворився дефіцит, який був профінансований за рахунок випуску нових асигнацій (44,3 млн. рублів) (Мигулин, 1899: 48). Крім того, непосильний тягар нагромаджених за минулі роки боргів і фактичний провал приватизації державного майна (було отримано не більше 20 \% від запланованої суми) також не дозволили відмовитися від чергового траншу асигнацій.

Друга частина «Плану фінансів» присвячена розвитку фінансів після 1810 р. Вона складалася 3 чотирьох частин: про витрати, про доходи, про влаштування монетної та кредитної системи, про управління фінансами (Печерин, 1896: 23). У результаті прийняття цього плану мала бути реалізованою найголовніша фінансова ідея того часу - збалансованість дохідної та витратної частин бюджету. Причому витратна частина розподілялася за такими класифікаційними призначеннями: за різними відомствами; за ступенем необхідності витрат (необхідні, корисні, надлишкові); за територією (загальнодержавні, губернські, окружні, волостні); за призначенням (звичайні та надзвичайні, причому для останніх планувався не обсяг коштів, а спосіб їх накопичення) (Печерин, 1896: 23-26). Крім того, планом були детально класифіковані державні доходи, поділені на три головні види. 1. Податі і податки (подушне, мита, за гербовий папір, збір поземельний у містах та деяких губерніях, збір з купців і міщан, відрахування з платні, збір з паспортів, земські повинності, збори волосні на віддачу рекрут, на утримання волосних правлінь та інші внутрішні витрати, збір митний. 2. Доходи з казенних капіталів (А. Доходи з капіталів, котрі казна використовує на виготовлення продукції: руди, солі, ловля риби, звіроловство. Б. Доходи з капіталів, котрі казна отримує 3 промисловості й торгівлі: казенні фабрики, винятковий питний продаж, пошта. В. Доходи з капіталів, котрі казна отримує з утримання різних громадських закладів: дороги, канали, монети, банки). 3. Доходи від казенної власності (казенні землі, різні оброчні статті, ліси) (Печерин, 1896: 27-28).

Отже, інноваційність стратегії «Плану фінансів» полягала у двох важливих рішеннях - у припиненні випуску незабезпечених асигнацій та переході до погашення бюджетних боргів за рахунок підвищення податків. Зазначимо, що якби уряд Олександра I дотримувався цих ідей, то неможливо було б вести безплідні війни з Францією, так як підвищення податків ніколи б не могло дати фінансового забезпечення цих воєн, яке могли б легко забезпечити випуски асигнацій (Мигулин, 1899: 47).

Наступним розпорядженням став маніфест 13 квітня 1810 р. про створення в асигнаційному банку облікових контор та про визначення обсягу обігових асигнацій. Згідно з цим документом, гірські банківські заводи стали державними, всі запасні капітали та залишкові суми усіх відомств передані у розпорядження державному казначейству, розрахунки казначейства з банком тимчасово припинені (при цьому борги банку від клієнтів переведені для отримання казначейством, дорогоцінні метали 3 банку та прибутки від діяльності облікових контор також передані до казначейства), обсяг обігових асигнацій було визначено сумою 577 млн. рублів (Блиох, 1882: 98), (Мигулин, 1899: 48). А маніфестом від 27 травня 1810 р. було оголошено про відкриття термінового внутрішнього займу для зменшення обсягу асигнацій та погашення державних боргів. Заїм був відкритий на суму 100 млн. рублів (розділявся на п’ять розрядів, облігації приносили вкладникам 6 \% річних з поверненням у 1817 р. сріблом чи золотом з розрахунку 2 рублі асигнаціями за 1 рубель сріблом; безстрокові ж капітали приймалися під 4 \% річних з розрахунку 1,5 рубля асигнаціями за 1 рубль сріблом). Зазначимо, що реальний курс асигнаційного рубля на момент займу складав 3,24 рубля за 1 срібний рубль (Блиох, 1882: 99), (Мигулин, 1899: 50). На травень місяць 1811 р. вдалося повністю реалізувати першу частину займу, основною метою якого займу П. Мігулін називає консолідування боргів державними кредитними установами та вилучення з обігу зайвої кількості асигнацій (Мигулин, 1899: 51-52). Продовження займу не відбулося через розпочату 1811 року підготовку до війни з Наполеоном.

Нарешті, маніфестом від 20 липня 1810 р. було затверджено нову структуру монетної системи - головною монетною одиницею визначений срібний рубль (з еквівалентом ваги 100 рублів рівної 5 фунтам та 6 золотникам лігатурного срібла 83푹 проби) (Блиох, 1882: 100), (Мигулин, 1899: 53). Було вирішено у всіх фінансових документах 31 січня 1811 р. використовувати саме срібний рубль. При цьому російська монета була розділена на три розряди: монета банкова та торгова (срібний рубль та полтина); монета срібна розмінна (20, 10 та 5 копійок); монета мідна розмінна (2, 1 та півкопійки).

27 травня 1810 р. було створено Комісію погашення державних боргів (ПСЗРИ: 198), а 6 липня 1810 р. - затверджено іiі статут (Блиох, 1882: 100) (створена тоді комісія проіснувала фактично до 
1917 р.). Саме ця комісія займалася випуском облігацій державної позики 27 травня 1810 р. та розпродажем державного майна. Через фактичну відсутність чіткої внутрішньої організації тодішньої структури міністерств М. Сперанський та М. Балудянський спланували зміни у системі виконавчої влади, що полягали в такому: оптимізація структури розподілу відомств, і їх внутрішньої структури, зміна розподілу посадових обов'язків міністрів та його підлеглих. Як наслідок, маніфестом від 25 липня 1810 р. вся виконавча влада була розділена на п'ять частин: зовнішніми відносинами мало займатися міністерство іноземних справ; влаштуванням зовнішньої безпеки - військове та морське міністерства; державною економією - міністерства внутрішніх справ, народної освіти та фінансів, державне казначейство, ревізія державних рахунків (державний контроль), головне управління шляхів сполучення; влаштуванням суду - міністерство юстиції; влаштуванням внутрішньої безпеки міністерство поліції (Блиох, 1882: 104). У результаті управління державними доходами та витратами здійснювали три державні структури: міністерство фінансів, державне казначейство та державний контроль (спеціальний маніфест від 28 січня 1811 р. містив детальну інструкцію для організації головного управління ревізії державних рахунків). Міністерство фінансів відповідало за всі джерела доходів (управління державним майном, монетними, банковими, митними, гірськими та соляними справами, зборами та митами, грошовими повинностями, міськими та земськими доходами). Державне казначейство мало забезпечувати оборот доходів та витрат, виплату боргів та пансіонів, накопичувати бюджетні запаси. Державний контроль мав ревізувати всі державні рахунки.

Маніфест від 25 червня 1811 р. став логічним продовженням маніфесту про зміну структури виконавчої влади і визначав коло обов'язків кожного із міністерств (особливо детально були внормовані саме фінансові обов'язки державних відомств). Згідно з цим маніфестом дорадчий елемент був представлений двома закладами - загальною нарадою відділень для департаменту та радою міністра для всього міністерства. Виконавча частина міністерства фінансів складалася з канцелярії міністра (відповідала за справи, що стосувалися роботи всього міністерства та розподіляла справи між департаментами) і департаментів, кожен з яких відповідав за конкретну галузь діяльності та складався з відділень (Блиох, 1882: 105-107). Департамент державного майна працював у складі відділень: головного відомства казенних селян; орендних та старостівських маєтків; корабельних лісів; казенних лісів; господарських закладів. Департамент гірських та соляних справ об'єднував такі відділення: монетне; казенних заводів; приватних заводів; добування солей та мінералів; постачання солі державі. У департаменті зовнішньої торгівлі функціонували два відділення: торгових зовнішніх відносин та митного управління. Департамент податків та зборів мав у своєму складі відділення: податей та повинностей; питних зборів; гербового паперу. При цьому кожній структурній одиниці міністерства (в тому числі і міністру фінансів) була визначена відповідна субординаційна вага. 3 метою створення міжміністерського органу управління М. Сперанський запропонував розділити сенат на урядовий, який би складався з міністрів, їх товаришів та керівників окремих управлінь, і судовий, у складі сенаторів від корони та сенаторів за вибором від дворянства (з перебуванням останнього в Петербурзі, Москві, Києві та Казані). У червні 1811 р. після подолання спротиву консерваторів (так назвали тих, які прагнули зберегти за собою привілеї, що давали свободу доступу до царської милості) цей проект був підтриманий державною радою та затверджений Олександром I.

М. Сперанський та М. Балудянський планували також упорядкувати систему укладання розписів доходів та витрат Російської імперії, які підкріплювалися б звертанням до довіри суспільства та характеризувалися гласністю операцій (Блиох, 1882: 110). 29 серпня 1810 р. державною радою було прийняте рішення про початок складання державного кошторису на 1812 р. не пізніше червня 1811 р. (всі міністерства надають свої кошториси до міністерства фінансів), а не пізніше жовтня місяця 1811 р. міністерство фінансів мало подати на розгляд державної ради загальний кошторис.

М. Сперанський успішно розв'язував також фінансові проблеми тактичного характеру. Так, у вересні 1810 р. при міністрові фінансів була створена тимчасова комісія 3 питань постачання державі солі (якраз на той час з'явилося багато нарікань на соляне забезпечення потреб держави). Комісія у складі чотирьох осіб («без различия чинов и состояний, из людей, знающих весь ход развозки соли» (Блиох, 1882: 111)) успішно в короткі терміни справилася із завданням. А в грудні місяці того ж року був виданий маніфест про новий митний тариф, який дав змогу пожвавити ро- 
сійську фабричну промисловість та підвищив рівень їі конкурентоспроможності порівняно із європейськими виробництвами. Новий тариф зумовив розширення експортних операцій та продумане згортання імпортних (необхідні для держави товари обкладалися меншим митом i, навпаки, менш необхідні - більшим; на ввезення предметів розкоші взагалі була накладена заборона).

Зазначимо, що описані плани та проекти державних перетворень М. Сперанського та М. Балудянського хоч і були схвалені державною радою і царем, лише частково були впроваджені у життя. Війна, зміна в долі самого М. Сперанського, різка зміна поглядів Олександра I - все це ускладнило реалізацію запропонованих реформ (Блиох, 1882: 109).

Реалізацію одного з напрямів фінансового управління покажемо через проведення статистичного аналізу фактичного виконання фінансових розписів за період 1810 - 1814 рр. Розгляд розпису державних доходів і витрат Російської імперії протягом XIX ст. (і особливо періоду до 1862 р.) пов’язаний з певними труднощами, спричиненими реаліями обліку та контролю, що були характерними для цієї держави у зазначений період. Основна причина труднощів у проведенні дослідження пов'язана з фактичною відсутністю точних даних протягом усього століття. І це при тому, що з 1862 р. бюджетні показники Російської імперії почали публікувати у відкритих джерелах, а 31863 р. міністерство фінансів Російської імперії докорінно реформувало систему обліку та контролю фінансового обороту в державі. У різних джерелах загальні дані по Російській імперії, представлені за різними міністерствами та відомствами, є досить суперечливими (див. порівняння джерел (Блиох, 1882), (Министерство финансов, 1902a), (Министерство финансов, 1902b), (Исторический бюджет России), (Печерин, 1896) та (Мигулин, 1899)). Більше того, досить часто різнилися дані, які виходили з одного і того ж міністерства. Протягом шести десятиліть ХIX ст. витримувалася закладена ще в епоху Петра I традиція щодо нерозголошення особливостей формування показників загального бюджету держави, втаємничення показників воєнних витрат, загального державного боргу, доходів від питного збору та інші дані фінансового становища держави. Але навіть якби перелічена інформація була доступною для аналізу фахівцями-істориками, то все одно об'єктивної та кількісно точної картини розвитку російських фінансів відтворити не вдасться. Адже навіть після «облікової революції» 1863 р. кожне міністерство, крім коштів бюджетних, мало так звані «свої кошти», якими відповідні чиновники розпоряджалися на власний розсуд (недаремно російський цар Микола I для характеристики цього явища використав вислів - «Росією управляють столоначальники»). Ми так і не знайшли в джерелах бодай наближених офіційних оцінок обсягів «позабюджетних» коштів, які не могли бути обраховані у російських розписах. Але, за свідченнями, викладеними в (Блиох, 1882), є очевидним той факт, що левова частка цих коштів не використовувалися на підтримку діяльності відповідних міністерств та на виконання державних програм того часу, а банально присвоювалася чиновниками.

Розглянемо динаміку базових показників виконання бюджетів Російської імперії протягом $1801-1814$ рр. (рис. 1).

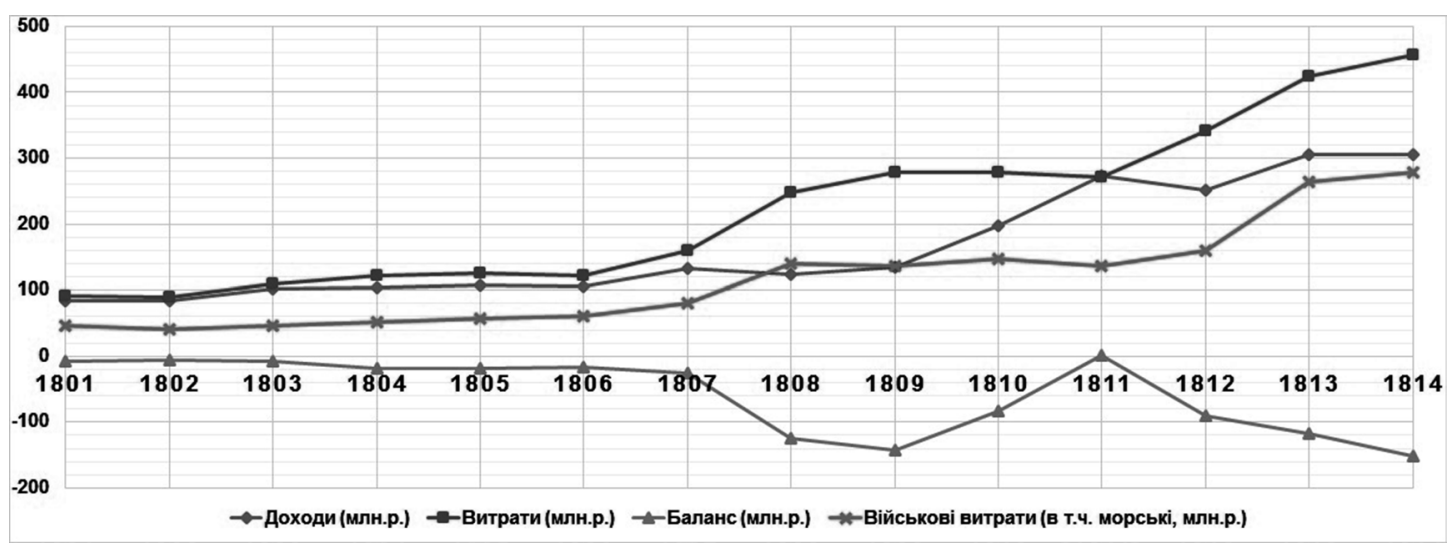

Рисунок 1. Динаміка базових показників бюджетів Російської імперії протягом 1801 - 1814 років. 
Джерелом статистичних даних для побудови діаграми нам послугувала праця П. Мігуліна (Мигулин, 1899). Близькі до вказаних у цьому джерелі показники виконання бюджетів Російської імперії, зазначені І. С. Бліохом (Блиох, 1882). У джерелах (Министерство финансов, 1902a), (Исторический бюджет России) та (Печерин, 1896) містяться лише планові показники, які, як правило, не виконувалися. Цей період взятий для аналізу з метою показати, як відобразився початок реформ М. Сперанського на фінансовому становищі імперії, та як зміна поглядів Олександра I і війни, що вела Російська імперія протягом цього періоду, фактично нівелювали результати описаних вище системних перетворень. Дослідники розвитку фінансів Російської імперії того періоду (див. (Блиох, 1882), (Министерство финансов, 1902а, (Мигулин, 1899), (Корф, 1861), (Печерин, 1896)) відзначають катастрофічно негативний вплив участі Росії у військових кампаніях початку XIX ст. За цей період імперія воювала з Туреччиною, Францією, потім з Англією, зі Швецією, нарешті знову з Францією. 3 жодної з перелічених війн Російська імперія не отримала вагомих дивідендів - «это безусловно были войны за идеи, бесцельные и разорительные для России... Именно со времен Александра І в Западной Европе стали смотреть на Россию враждебно и с явным страхом к завоевательным ее тенденциям. Отсюда - та глубокая (иногда тайная) ненависть, которую питают к России почти все народы Европы, отсюда их постоянная готовность к враждебным действиям против России и радость по случаю русских неудач» (Мигулин, 1899: 43-44). Навіть 3 тих воєн, які могли «слугувати на користь» Російській імперії і закінчилися для неї успішно (зі Швецією та Туреччиною), уряд не зміг отримати ніякого матеріального зиску.

Саме 31806 р. почали стрімко збільшуватися воєнні витрати Росії, тоді ж баланс фінансів імперії ставав критичним, досягнувши свого мінімуму у 1809 р. Курс асигнаційного рубля впав до третини срібного рубля (Мигулин, 1899: 45). Скоротилися також і вексельні курси, на які суттєво вплинуло припинення торгівлі з Англією (через так звану континентальну систему, що була введена вимогами Тільзітського трактату з Францією). Саме в цей момент були вжиті заходи для поліпшення фінансового становища імперії. Результати революційних перетворень М. Сперанського та М. Балудянського бачимо з макропоказників (див. рис. 1) 1810 та 1811 рр. - через впровадження «Плану фінансів» дохідна частина бюджету різко зросла (план зростання - див. таблицю 1), витратна - дещо скоротилася, причому станом на 1811 р. між ними майже був досягнутий паритет. Уже у 1811 р. розпочалася підготовка до другої війни з Францією. Процес підготовки до війни та сама воєнна кампанія знову спричинили зростання витрат на утримання військ та підтримку їхньої боєздатності і, як наслідок, до різкого зростання бюджетного дефіциту.

Таблиця 1. Зіставлення планування дохідної частини бюджету Російської імперії 1809 та 1810 pp. (в млн. рублів, джерело - (Печерин, 1896: 19-20))

\begin{tabular}{|c|c|c|c|c|}
\hline № & Назви зборів & $\begin{array}{c}\text { За попередніми } \\
\text { нормами }\end{array}$ & Приріст & В підсумку \\
\hline \multicolumn{5}{|c|}{ Окладні незмінні (в млн. рублів) } \\
\hline 1 & 3 капіталів купців & 3,75 & 1,5 & 5,25 \\
\hline 2 & Податі з селян, що торгують у столиці & & 0,44 & 0,44 \\
\hline 3 & 3 міщан та цехових & 1,77 & 1,24 & 3,01 \\
\hline 4 & 3 іноземних ремісників у столицях & & 0,38 & 0,38 \\
\hline 5 & 3 однодвірців та казенних селян & 28,46 & 15,19 & 43,65 \\
\hline 6 & 3 селян удільних & 1,39 & 0,58 & 1,97 \\
\hline 7 & з них же «одночасно» & & 0,32 & 0,32 \\
\hline 8 & 3 селян поміщицьких та дворцових людей & 13,22 & 5,14 & 18,36 \\
\hline 9 & 3 них же «одночасно» по 50 к. з душі & & 5,08 & 5,08 \\
\hline 10 & Подимні в литовських губерніях & 0,74 & 0,37 & 1,11 \\
\hline \multirow{2}{*}{$\frac{11}{12}$} & з них же пожертви & 0,79 & & 0,79 \\
\hline & Орендних в казенних маєтках & 4,26 & & 4,26 \\
\hline & Всього & 54,38 & 30,24 & 84,62 \\
\hline
\end{tabular}




\begin{tabular}{|c|c|c|c|c|}
\hline \multicolumn{5}{|c|}{ Окладні змінні (в млн. рублів) } \\
\hline 1 & Відкупних та за вино & 36,92 & & 36,92 \\
\hline 2 & 3 оброчних статей & 1,02 & & 1,02 \\
\hline 3 & 3 приватних гірських заводів & 1 & 0,34 & 1,34 \\
\hline 4 & 3 єзуїтських маєтків та капіталів & 0,43 & & 0,43 \\
\hline 5 & Півпроцентні з будинків в столицях & & 0,93 & 0,93 \\
\hline & Всього & 39,37 & 1,27 & 40,64 \\
\hline \multicolumn{5}{|c|}{ Неокладні (в млн. рублів) } \\
\hline 1 & Митних зборів & 6 & 4,86 & 10,86 \\
\hline 2 & Від продажу солі & 9,56 & 7,39 & 16,95 \\
\hline 3 & Із золота, срібла, заліза, міді на казенних заводах & 1,22 & & 1,22 \\
\hline 4 & Лісових доходів & 0,73 & & 0,73 \\
\hline 5 & Подорожнього збору & 0,45 & & 0,45 \\
\hline 6 & За паспорти & 1,83 & 1,02 & 2,85 \\
\hline 7 & За гербовий, вексельний та заємний папір & 1,72 & 0,45 & 2,17 \\
\hline 8 & Боргові від С.-Петерб. магазинів & 1,18 & & 1,18 \\
\hline 9 & Рекрутських грошей, замість рекрут & 0,13 & & 0,13 \\
\hline 10 & Залишок від поштового доходу & 1 & & 1 \\
\hline 11 & Мита, штрафні та інші & 6,63 & & 6,63 \\
\hline \multicolumn{2}{|r|}{$\begin{array}{rr}\text { Разом } \\
\end{array}$} & 30,45 & 13,72 & 44,17 \\
\hline \multicolumn{2}{|r|}{ Разом доходів } & 124,2 & 45,23 & 169,43 \\
\hline
\end{tabular}

3 метою оцінки якості зміни показників бюджетів Російської імперії протягом періоду 1801 1814 рр. ми побудували лінійні тренди зміни показників доходів, витрат та воєнних витрат (у тому числі морських). В результаті аналізу лінійних трендів ми отримали, що доходи імперії за вказаний період зростали з лінійним коефіцієнтом 18,4 (при цьому величина достовірності апроксимації (наближення до реальних значень) була досить великою і сягнула 0,85 ), воєнні витрати імперії зростали з лінійним коефіцієнтом 17,2 (величина достовірності апроксимації при цьому рівна 0,84), а загальні витрати бюджету Російської імперії зростали з лінійним коефіцієнтом 28,3 (при цьому величина достовірності апроксимації досягнула позначки 0,91). Як бачимо, обсяг зростання воєнних витрат Російської імперії протягом зазначеного періоду фактично поглинав обсяг зростання загальних доходів бюджету i, як наслідок, займав левову частку обсягу загальних витрат бюджету країни.

У зв'язку з розпочатою підготовкою до війни з Францією реформи були заморожені, а після відставки та дискредитації самого реформатора М. Сперанського їх взагалі визнали шкідливими та неактуальними.

Висновки. Теоретичні ідеї та практична діяльність державних діячів М. Сперанського та М. Балудянського посідають важливе місце в історії фінансового управління Російської імпеpiï. Завдяки розробкам цих діячів: а) регламентовано процес щорічного затвердження бюджету, надання йому статусу державного закону, у якому об'єднувалися всі доходи і витрати в рамках єдиного відомства - міністерства фінансів; б) обговорення представниками вищих прошарків Російської імперії і прийняття першого державного бюджету державною радою стало презентацією публічних та цивілізованих норм управління державними фінансами того часу; в) задекларований жорсткий контроль над запланованими витратами і доходами відомств, що, крім іншого, передбачав персональну відповідальність чиновників; г) проголошена єдина бюджетна класифікація доходів і витрат для бюджетів усіх рівнів; д) протягом перших двох років реформування за рахунок підвищення податків вдалося збільшити дохідну частину бюджету та суттєво зменшити його дефіцит; є) з часу оформлення міністерської системи управління розробка державних бю- 
джетів стала доцільним і обгрунтованим процесом, з'явилася можливість аналізувати бюджетну політику держави на основі не припущень, а достовірних цифр.

2. Указані теоретико-практичні досягнення реформаторів так і не були реалізовані в повному обсязі на початку XIX ст. через постійну участь Російської імперії у воєнних кампаніях, що вело до неконтрольованого росту військових бюджетів, через чиновницьку корумпованість та елементарне невиконання розпоряджень центральної влади Багато їхніх ідей знайшли впровадження у далеко пізніший період історії фінансів Російської імперії.

\section{СПИСОК ВИКОРИСТАНИХ ДЖЕРЕЛ І ЛІТЕРАТУРИ}

Алмазов, 1889 - Алмазов Б. Н. Критико-биографический словарь русских писателей и ученых (от начала образованности до наших дней). Санкт-Петербург: Семеновская тип. лит. (И. Эфрона), 1889. С. 80-83.

Балудянский, 1806а - Балудянский М. Национальное богатство. Изображение различных хозяйственных систем // Статистический журнал. 1806. Т. 1. Ч. 1. С. 45-71.

Балудянский, 1806b - Балудянский М. О национальном богатстве // Статистический журнал. 1806. Т. 1. Ч.2. С. 33-70.

Балудянский, 1808 - Балудянский М. О разделении и обороте богатства // Статистический журнал. 1808. Т. 2. Ч.2. С. $1-76$.

Бец, 2013 - Бец О. І. Еволюція наукових концепцій державного кредиту і державного боргу // Ринок цінних паперів України. 2013. № 9-10. С. 39-45.

Блиох, 1882 - Блиох И. С. Финансы России XIX столетия: история - статистика. С.-Петербург: Типография М.М. Стасюлевича, 1882. Том 1. 344 с.

Голубка, 2012 - Голубка С. М. Балудянський - реформатор і теоретик основних засад фінансово-економічної науки // Економіка України. 2012. № 7. С. 89-95.

Игнатенко, 2012 - Игнатенко Д. И. Административно-правовой статут министерства финансов России, правовое регулирование деятельности министров финансов // «Черные дыры» в российском законодательстве. 2012. № 3. С. 106-108.

Исторический бюджет России - Исторический бюджет России (Общие государственные росписи доходов и расходов на 1867 - 1917 гг.) [Електронний ресурс]. Режим доступу: http://istmat.info/node/47078

Корнилов, 1993 - Корнилов А. А. Курс истории России XIX века. Москва: Высшая школа, 1993. 447 с.

Корф, 1861 - Корф М. А. Жизнь графа Сперанского. Санкт-Петербург: Издание Императорской Публичной библиотеки, 1861. Т. 1. (ч. 1 и 2). 283 с.

Лісовенко та ін., 2014 - Лісовенко В. В., Бенч Л. Я., Бец О. І. Державний борг: концептуальні засади та макроекономічні аспекти // Фінанси України. 2014. № 12. С. 7-31.

Лушникова, Лушников, 2013а - Лушникова М. В., Лушников А. М. Развитие науки финансового права в России. Учебное пособие. Москва, ООО «Юридический центр-Пресс», 2013. 960 с.

Лушникова, Лушников, 2013b - Лушникова М. В., Лушников А. М. Российская школа финансового права: портреты на фоне времени. Монография. Ярославль: ЯрГУ, 2013. 640 с.

Мигулин, 1899 - Русский государственный кредит (1769 - 1899): опыт историко-критического обзора. Харьков, Типо-лит. «Печатное дело», кн. К.Н. Гагарина, 1899, т. 1. Електронний ресурс. - режим доступу: https://www.prlib.ru/item/442534

Министерство финансов, 1902a - Россия. Министерство финансов. 1802 - 1902: (Ист. обзор главнейших мероприятий фин. ведомства: Ч. 1-2) / Печатано с разрешения Министерства финансов. С.-Петербург: Экспедиция заготовления гос. бумаг, 1902, частина 1. [Електронний ресурс]. Режим доступу: http://elib.shpl.ru/ nodes $/ 4341$

Министерство финансов, 1902b - Россия. Министерство финансов. 1802 - 1902: (Ист. обзор главнейших мероприятий фин. ведомства: Ч. 1-2) / Печатано с разрешения Министерства финансов. С.-Петербург: Экспедиция заготовления гос. бумаг, 1902, частина 2. [Електронний ресурc]. Режим доступу: http://elib.shpl.ru/ nodes $/ 4341$

Морозов, 2011 - Морозов О. В. Митна система Російської імперії в українських губерніях XVIII - початок XX ст.: Монографія. Дніпропетровськ: АМСУ, 2011. 312 с.

Небрат, 2013 - Небрат В. В. Еволюція теорії державних фінансів в Україні: Монографія. НАН України, Ін-т екон. та прогнозув. Київ, 2013. 584 с.

Орлик, 2007 - Орлик В. М. Податкова політика Російської імперії в Україні в дореформений період: Монографія. Кіровоград: Імекс-ЛТД, 2007. 631 с.

Печерин, 1896 - Печерин Я. И. Исторический обзор росписей государственных доходов и расходов с 1803 по 1843 год включительно. Санкт-Петербург: Типография Ю. Н. Эрлих, 1896, 220 с.

ПСЗРИ - Полное собрание законов Российской империи. Собр. 1. Т. XXXI. № 24244. С. 198. 
Фатеев, 1931 - Фатеев А. Н. Академическая и государственная деятельность М. А. Балудянского в России. Ужгород, 1931. 64 с.

Хохуляк, 2012 - Хохуляк В. В. Проекти комплексного реформування системи державних фінансів М.А. Балудянського та їх вплив на становлення вітчизняної науки фінансового права // Науковий вісник Ужгородського нац-го ун-ту. Серія «Право». 2012. Вип. 20. Ч. 1. Т. 3. С. 234-236.

Чуркіна, 2014 - Чуркіна I. С. Еволюція наукових концепцій щодо проблематики бюджетної системи // Вісник соціально-економічних досліджень. 2014. Вип. 2 (53). С. 164-172.

\section{REFERENCES}

Almazov, 1889 - Almazov B. N. Krytyko-byohrafycheskyy slovar' russkykh pysateley y uchenykh (ot nachala obrazovannosty do nashykh dney) [The critical-biographical dictionary of the Russian writers and scientists (from the beginning of education to our days)]. SPb.: Semenovskaya typ.lyt. (Y. Efrona), 1889. S. 80-83. [in Russian].

Baludyanskyy, 1806a - Baludyanskyy M. Natsyonal'noe bohatstvo. Yzobrazhenye razlychnykh khozyaystvennykh system [National wealth. Picture of various economic systems] // Statistical Journal. 1806. Volume 1. Part 1. S. 45-71. [in Russian].

Baludyanskyy, 1806b - Baludyanskyy M. O natsyonal'nom bohatstve [On National Wealth] // Statistical Journal. 1806. Volume 1. Part 2. S. 33-70. [in Russian].

Baludyanskyy, 1808 - Baludyanskyy M. O razdelenyy y oborote bohatstva [On the division and circulation of wealth] // Statistical Journal. 1808. Volume 2. Part 2. S. 1-76. [in Russian].

Bets, 2013 - Bets O. I. Evolyutsiya naukovykh kontseptsiy derzhavnoho kredytu i derzhavnoho borhu [The evolution of the scientific concepts of Public Credit and Public Debt] // Stock Market of Ukraine. 2013. № 9-10. S. 39-45. [in Ukrainian].

Blyokh, 1882 - Blyokh Y. S. Fynansy Rossyy XIX stoletyya: ystoryya - statystyka [The Finances of Russia in XIX centuries: history - statistics]. St. Petersburg: Printing house M. M. Stasyulevych, 1882, Volume 1. 344 s. [in Russian].

Holubka, 2012 - Holubka S. M. Baludyans'kyy - reformator i teoretyk osnovnykh zasad finansovoekonomichnoyi nauky [Baludyansky - the reformer and theorist of the basic principles of financial and economic science] // Economy of Ukraine. 2012. № 7. S. 89-95. [in Ukrainian].

Yhnatenko, 2012 - Yhnatenko D. Y. Admynystratyvno-pravovoy statut mynysterstva fynansov Rossyy, pravovoe rehulyrovanye deyatel'nosty mynystrov fynansov [Administrative and legal status of the Ministry of Finance of Russia, legal regulation of the activity of the finance ministers] // «Black Holes» in the Russian legislation. 2012. № 3. S. 106-108. [in Russian].

Ystorycheskyy byudzhet Rossyy - Ystorycheskyy byudzhet Rossyy (Obshchye hosudarstvennыe rospysy dokhodov y raskhodov na 1867 - 1917 hh.) [The Historical Budget of Russia (General State Paintings of Income and Expenditures for 1867 - 1917)]. Retrieved from:_http://istmat.info/node/47078 [in Russian]

Kornylov, 1993 - Kornylov A. A. Kurs ystoryy Rossyy XIX veka [The history course of Russia in the XIX century]. Moskva: High School, 1993. 447 s. [in Russian].

Korf, 1861 - Korf M. A. Zhyzn' hrafa Speranskoho [Life of Count Speransky]. St. Petersburg: Publication of the Imperial Public Library, 1861. Volume 1. (Parts 1 y 2). 283 s. [in Russian].

Lisovenko ta in., 2014 - Lisovenko V. V., Bench L. Ya., Bets O. I. Derzhavnyy borh: kontseptual'ni zasady ta makroekonomichni aspekty [State Debt: Conceptual Principles and Macroeconomic Aspects] // Finance of Ukraine. 2014. № 12. S. 7-31. [in Ukrainian].

Lushnykova, Lushnykov, 2013a - Lushnykova M.V., Lushnykov A.M. Razvytye nauky fynansovoho prava v Rossyy. Uchebnoe posobye [The development of the science of Financial Law in Russia. Textbook]. Moskva, LLC «Legal Center-Press», 2013. 960 s. [in Russian].

Lushnykova, Lushnykov, 2013b - Lushnykova M. V., Lushnykov A. M. Rossyyskaya shkola fynansovoho prava: portrety na fone vremeny. Monohrafyya [Russian school of Financial Law: portraits on the background of time. Monograph]. Yaroslavl': YarHU, 2013. 640 s. [in Russian].

Myhulyn, 1899 - Russkyy hosudarstvennyy kredyt (1769-1899): opyt ystoryko-krytycheskoho obzora [The Russian state credit (1769 - 1899): experience of historical and critical review]. Khar'kov: Typo-lyt. «Pechatnoe delo», kn. K.N. Haharyna, 1899. Volume 1. Retrieved from:_https://www.prlib.ru/item/442534 [in Russian]

Mynysterstvo fynansov, 1902a - Rossyya. Mynysterstvo fynansov. 1802-1902: (Yst. obzor hlavneyshykh meropryyatyy fyn. vedomstva: Ch. 1-2) [Russia. Ministry of Finance. 1802-1902: (Historical review of the main activities of the financial department: parts 1-2)] / Printed with the permission of the Ministry of Finance. St.-Peterburg: Storing expedition of the governmental papers, 1902, part 1. Retrieved from:_http://elib.shpl.ru/ nodes/4341 [in Russian] 
Mynysterstvo fynansov, 1902b - Rossyya. Mynysterstvo fynansov. 1802 - 1902: (Yst. obzor hlavneyshykh meropryyatyy fyn. vedomstva: Ch. 1-2) [Russia. Ministry of Finance. $1802-1902$ : (Historical review of the main activities of the financial department: parts 1-2)] / Printed with the permission of the Ministry of Finance. St.-Peterburg: Storing expedition of the governmental papers, 1902, part 2. Retrieved from:_http://elib.shpl.ru/ nodes/4341 [in Russian]

Morozov, 2011 - Morozov O. V. Mytna systema Rosiys'koyi imperiyi v ukrayins'kykh huberniyakh XVIII pochatok XX st.: Monohrafiya [Customs System of the Russian Empire in the Ukrainian Provinces of the XVIII - beginning of the XXth Century: Monograph]. Dnipropetrovs'k: AMSU, 2011. 312 s. [in Ukrainian].

Nebrat, 2013 - Nebrat V. V. Evolyutsiya teoriyi derzhavnykh finansiv v Ukrayini: Monohrafiya [The evolution of the theory of public finances in Ukraine: Monograph]. National Academy of Sciences of Ukraine, Institute of Economics and Forecasting. Kyiv, 2013. 584 s. [in Ukrainian].

Orlyk, 2007 - Orlyk V. M. Podatkova polityka Rosiys'koyi imperiyi v Ukrayini v doreformenyy period: Monohrafiya [Tax policy of the Russian Empire in Ukraine in the pre-reform period: Monograph]. Kirovohrad, Imeks-LTD, 2007. 631 s. [in Ukrainian].

Pecheryn, 1896 - Pecheryn Ya. Y. Ystorycheskyy obzor rospysey hosudarstvennykh dokhodov y raskhodov s 1803 po 1843 hod vklyuchytel'no [The historical overview of government revenues and expenditures from 1803 to 1843]. Sankt-Peterburh: Typography Yu.N. Erlich. 1896. 220 s. [in Russian].

PSZRY - Polnoe sobranye zakonov Rossyyskoy ymperyy. Sobr. 1 [Complete collection of laws of the Russian Empire. Coll. 1]. Vol. XXXI. № 24244. S. 198 [in Russian].

Fateev, 1931 - Fateev A. N. Akademycheskaya y hosudarstvennaya deyatel'nost' M. A. Baludyanskoho v Rossyy [The academic and state activity of M. A. Baludiansky in Russia]. Uzhhorod, 1931. 64 s. [in Russian].

Khokhulyak, 2012 - Khokhulyak V. V. Proekty kompleksnoho reformuvannya systemy derzhavnykh finansiv M. A. Baludyans'koho ta yikh vplyv na stanovlennya vitchyznyanoyi nauky finansovoho prava [The projects of complex reforms of the public Finance System of M. A. Baludiansky and their influence on the formation of domestic science of financial law] // The scientific herald of Uzhgorod National University. The series «Pravo». 2012. Issue 20. Part 1. Vol. 3. S. 234-236. [in Ukrainian].

Churkina, 2014 - Churkina I. Ye. Evolyutsiya naukovykh kontseptsiy shchodo problematyky byudzhetnoyi systemy [The evolution of the scientific concepts on the problems of the Budget System] // Bulletin of Social and Economic Research. 2014. Issue 2 (53). S. 164-172. [in Ukrainian].

Стаття надійшла до редакиї̈ 9.02.2018 p. 